\title{
Synergistic effects of iron and temperature on Antarctic phytoplankton and microzooplankton assemblages
}

\author{
J. M. Rose ${ }^{1}$, Y. Feng ${ }^{2}$, G. R. DiTullio ${ }^{3}$, R. B. Dunbar ${ }^{4}$, C. E. Hare ${ }^{5}$, P. A. Lee ${ }^{3}$, M. Lohan ${ }^{6}$, M. Long ${ }^{4}$, W. O. Smith Jr. , \\ B. Sohst ${ }^{8}$, S. Tozzi ${ }^{7}$, Y. Zhang ${ }^{5}$, and D. A. Hutchins ${ }^{2}$ \\ ${ }^{1}$ Biology Department, Woods Hole Oceanographic Institution, Woods Hole, MA 02543, USA \\ ${ }^{2}$ Biology Department, University of Southern California, Los Angeles, CA 90089-0371, USA \\ ${ }^{3}$ Hollings Marine Laboratory, College of Charleston, Charleston, SC 29412, USA \\ ${ }^{4}$ Department of Environmental Earth Systems Science, Stanford University, Stanford, CA 94305-2115, USA \\ ${ }^{5}$ College of Marine Studies, University of Delaware, Lewes, DE 19958, USA \\ ${ }^{6}$ School of Earth, Ocean and Environmental Sciences, University of Plymouth, Plymouth PL4 8AA, UK \\ ${ }^{7}$ Virginia Institute of Marine Science, College of William and Mary, Gloucester Pt, VA 23602, USA \\ ${ }^{8}$ Department of Ocean, Earth and Atmospheric Sciences, Old Dominion University, Norfolk, VA 23529, USA
}

Received: 30 May 2009 - Published in Biogeosciences Discuss.: 19 June 2009

Revised: 14 October 2009 - Accepted: 11 November 2009 - Published: 21 December 2009

\begin{abstract}
Iron availability and temperature are important limiting factors for the biota in many areas of the world ocean, and both have been predicted to change in future climate scenarios. However, the impacts of combined changes in these two key factors on microbial trophic dynamics and nutrient cycling are unknown. We examined the relative effects of iron addition $(+1 \mathrm{nM})$ and increased temperature $\left(+4^{\circ} \mathrm{C}\right)$ on plankton assemblages of the Ross Sea, Antarctica, a region characterized by annual algal blooms and an active microbial community. Increased iron and temperature individually had consistently significant but relatively minor positive effects on total phytoplankton abundance, phytoplankton and microzooplankton community composition, as well as photosynthetic parameters and nutrient drawdown. Unexpectedly, increased iron had a consistently negative impact on microzooplankton abundance, most likely a secondary response to changes in phytoplankton community composition. When iron and temperature were increased in concert, the resulting interactive effects were greatly magnified. This synergy between iron and temperature increases would not have been predictable by examining the effects of each variable individually. Our results suggest the possibility that if iron availability increases under future climate regimes, the impacts of predicted temperature increases on plankton assemblages in polar regions could be significantly enhanced. Such synergistic and antagonistic interactions between individual climate change variables highlight the importance of multivariate studies for marine global change experiments.
\end{abstract}

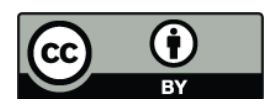

Correspondence to: D. A. Hutchins (dahutch@usc.edu)

\section{Introduction}

The Ross Sea, Antarctica is the location of one of the world's largest annual algal blooms (Smith et al., 2000). These algal blooms are characterized by spatial shifts in taxonomic composition across the region (Arrigo et al., 2000). The colonial prymnesiophyte Phaeocystis antarctica typically dominates phytoplankton assemblages of the southern and central polynya areas of the Ross Sea during mid- to late austral spring, peaking in early summer (DiTullio and Smith, 1996; Smith et al., 2003). Diatom assemblages, usually composed of Fragilariopsis and/or Thalassiosira, dominate the portions of the Ross Sea near the edge of the polynya, particularly in the west (Arrigo et al., 1999; Leventer and Dunbar, 1996). These and other diatom species such as Pseudonitzschia spp. are, however, also present throughout the polynya (Garrison et al., 2003). Heterotrophic protists have been reported to achieve high biomass in Antarctic marine systems (Caron et al., 2000; Dennett et al., 2001; Garrison, 1991; Garrison and Gowing, 1993). However, the impact of micro- and mesozooplankton grazing on phytoplankton assemblages dominated by colonial $P$. antarctica appears to be relatively minor (Caron et al., 2000; Haberman et al., 2003).

In the two decades since the pioneering experiments of Martin (1990) and deBaar (1990), iron limitation has come to be generally recognized as a primary "bottom-up" control on phytoplankton growth in the Southern Ocean. Both shipboard (Boyd et al., 1999; Hare et al., 2005; Hutchins et al., 2001; Scharek et al., 1997; Takeda, 1998) and in situ (Boyd et al., 2000; Coale et al., 2004; Gervais et al., 2002) experiments have repeatedly demonstrated that iron availability

Published by Copernicus Publications on behalf of the European Geosciences Union. 
strongly constrains the biology and biogeochemistry of most of the open high nutrient low chlorophyll (HNLC) Southern Ocean.

Parts of the coastal Southern Ocean are also strongly ironlimited, at least on a seasonal basis. As in other iron-limited continental shelf waters off California and Peru (Firme et al., 2003; Hutchins and Bruland, 1998; Hutchins et al., 2002), the combination of limited iron inputs and high biological demand leads to annually recurring summertime iron limitation in the southern Ross Sea (Coale et al., 2003; Martin et al., 1990; Maucher and DiTullio, 2003; Olson et al., 2000; Sedwick et al., 2000). In this region, mixed-layer dissolved $\mathrm{Fe}$ concentrations can be $<0.1 \mathrm{nM}$ during the growing season, (Coale et al., 2003; Fitzwater et al., 2000; Sedwick et al., 2000). Since melting sea ice may be a major source of biologically available iron (Sedwick and DiTullio, 1997), future changes in ice cover could lead to large shifts in the availability and timing of iron inputs in the Ross Sea.

In general, global change effects are expected to be manifested earlier and most severely in the Southern Ocean (Sarmiento et al., 1998). The Antarctic peninsula has experienced perhaps the fastest rate of warming and ice loss on the planet (Vaughan et al., 2003). In view of the expected minimum global temperature rise of $1-3^{\circ} \mathrm{C}$ over the next century (Alley et al., 2007), the broad future trends in coastal Antarctic ecosystems seem likely to include further widespread warming and ice retreat. If so, these changes in seasonal ice dynamics and accompanying increased stratification effects will lead to major changes in mixing regimes, nutrient supplies, and light environments experienced by Antarctic phytoplankton (Boyd and Doney, 2002; Montes-Hugo et al., 2009). Experiments in other high latitude regimes such as the Bering Sea and North Atlantic have already demonstrated the potential for significant effects of increased temperature on plankton assemblages, including changes in community composition, photosynthetic rates, nutrient drawdown and microbial food web dynamics (Feng et al., 2009; Hare et al., 2007; Rose et al., 2009).

Less is known for certain about future shifts in iron supplies to the iron-limited phytoplankton communities of the Ross Sea. Since the largest current sources of iron to surface waters here are vertical mixing and seasonal sea ice melting (Coale et al., 2003; Fitzwater et al., 2000; Martin et al., 1990; Sedwick and DiTullio, 1997; Sedwick et al., 2000), iron availability is highly vulnerable to anticipated climate change impacts. Reduction of these sources of iron to the Ross Sea under future global change scenarios would result in intensification of current iron limitation of phytoplankton growth. However, other potential sources of bioavailable iron could increase at the same time, such as melting glacial ice and icebergs (Overpeck et al., 2006; Raiswell et al., 2006, 2008) or even significant local aeolian input as snow cover retreats and exposes new soil on the adjacent continent. It has been suggested that the Ross Sea is freshening due to increased precipitation, decreased sea ice production and in- creased melting of the West Antarctic Ice Sheet (Jacobs et al., 2002). All of these can be significant sources of iron, so iron inputs to the Ross Sea may already be changing. Additionally, there is evidence that existing aeolian inputs from more distant continental sources such as Australia may change with a changing climate (Revel-Rolland et al., 2006). The future trends in iron inputs to the Ross Sea cannot be reliably predicted at present, but it seems inevitable that both iron supply and sea surface temperature will differ substantially from today's norms in the Ross Sea, with unknown consequences for regional food webs. In this study, we attempt to address this issue by examining the biological and biogeochemical interactions between iron availability and increased temperature in an experiment using a Ross Sea phytoplankton and microzooplankton community.

\section{Methods}

\subsection{Experimental design}

Experiments were conducted during the CORSACS (Controls On Ross Sea Algal Community Structure) expedition in January 2006 to the Ross Sea, Antarctica, onboard the RVIB Nathaniel B. Palmer (cruise NBP-0601). Water was collected at $75.00^{\circ} \mathrm{S}, 177.36^{\circ} \mathrm{E}$ using a trace metal clean towed-intake surface water Teflon diaphragm pumping system (Bruland et al., 2005). Water was prescreened through acid-washed $200 \mu \mathrm{m}$ Nitex mesh to eliminate large zooplankton and collected into a 50-L mixing carboy. Collected water was gently mixed and dispensed into 12 4.5-L acid washed trace metal clean clear polycarbonate bottles for incubation. Half of the bottles were spiked with $1.0 \mathrm{nM} \mathrm{FeCl}_{3}$ (final concentration) at the beginning of the experiment. Bottles were incubated in two temperature controlled deck-board incubators (Feng et al., 2009; Hare et al., 2007). Incubators were screened to $18 \%$ of $I_{\mathrm{o}}$ using two layers of neutral density filter. One incubator was kept at ambient temperature $\left(0^{\circ} \mathrm{C}\right)$, while the temperature in the other was gradually increased to $4^{\circ} \mathrm{C}$ over the course of $24 \mathrm{~h}$. Bottles were incubated for seven days and sampled daily under a laminar flow hood using trace metalclean techniques. Daily sampling included total chlorophyll, nanophytoplankton abundance, $F_{\mathrm{v}} / F_{\mathrm{m}}$ and dissolved nutrients. Additional samples were taken at time zero, on day 4 and the final day for $>20 \mu \mathrm{m}$ chlorophyll, particulate nutrients, diatom and microzooplankton abundance and biogenic sulfur. Samples for phytoplankton pigments (determined by HPLC) and total dissolved iron were taken on the initial and final days of the experiment. 


\subsection{Plankton assemblage measurements}

Chlorophyll samples (50-250 mL) were filtered onto either a $\mathrm{GF} / \mathrm{F}$ or a $20 \mu \mathrm{m}$ polycarbonate filter using low vacuum pressure. Samples were extracted for at least $24 \mathrm{~h}$ in the dark at $-20^{\circ} \mathrm{C}$ in $90 \%$ acetone and read on a Turner Designs fluorometer (Welschmeyer, 1994). Nanophytoplankton abundance was determined using flow cytometry. Two milliliters of sample were preserved in $1 \%$ seawater-buffered, $0.2 \mu \mathrm{m}$ filtered formalin (final concentration) and frozen at $-80^{\circ} \mathrm{C}$ until analysis. Samples were run on a FACSCalibur flow cytometer for $5 \mathrm{~min}$ on the high flow rate setting (Campbell, 2001). Nanophytoplankton were identified on twodimensional cytograms based on forward scatter (FSC) and red fluorescence (FL3).

Photochemical efficiency of PSII was measured using a MBARI 4th generation bench-top fast repetition rate fluorometer (FRRF) (Kolber et al., 1994). Samples were collected each day from experimental bottles, immediately placed on ice and kept in low light conditions (510 mol photons $\mathrm{m}^{-2} \mathrm{~s}^{-1}$ ) for $30-40 \mathrm{~min}$ prior to analysis. The light and cuvette chamber were constantly flushed with dry nitrogen gas to avoid condensation on the exterior of the cuvette due to the temperature difference between the cold seawater and the laboratory air. Minimal $\left(F_{0}\right)$ and maximal $\left(F_{\mathrm{m}}\right)$ fluorescence and the effective absorption cross section $(\sigma$ PSII) were calculated from each single turnover (ST) saturation curve. The maximum quantum yield efficiency for PSII $\left(F_{\mathrm{v}} / F_{\mathrm{m}}\right)$ was calculated (Genty et al., 1989$)$ by normalizing $F_{\mathrm{m}}$ by the difference between the fluorescence at saturation $\left(F_{\mathrm{m}}\right)$ and the minimum fluorescence $\left(F_{0}\right)$ :

$\Phi_{\mathrm{PSII}}^{\max }=\frac{F_{\mathrm{m}}-F_{0}}{F_{\mathrm{m}}}=\frac{F_{\mathrm{v}}}{F_{\mathrm{m}}}$

Samples for taxon-specific pigments $(600-1000 \mathrm{~mL})$ were filtered under low vacuum onto GF/F filters and frozen in liquid nitrogen until analysis using high performance liquid chromatography (HPLC). An automated Hewlett Packard 1100 HPLC system was used to separate pigments with a reverse-phase Waters Symmetry C-8 column and a solvent gradient containing methanol, aqueous pyridine, acetone, and acetonitrile (Zapata et al., 2000; DiTullio and Geesey, 2002). A diode array detector was used to record pigment spectra between the wavelengths 350 and $600 \mathrm{~nm}$, as well as continuous chromatograms at 410,440 , and $455 \mathrm{~nm}$ every $5 \mathrm{~s}$, and Chl- $a$ and $c$ were quantified with an HP 1046A fluorescence detector (excitation $421 \mathrm{~nm}$, emission $666 \mathrm{~nm}$ ). Unialgal laboratory cultures with the appropriate pigments were used to generate purified pigment standards for system calibration (DiTullio and Geesey, 2002).

Total diatom abundance and community composition was determined for samples preserved with $1 \%$ glutaraldehyde (final concentration) and stored in the dark at $4{ }^{\circ} \mathrm{C}$ until analysis. Twenty-five $\mathrm{mL}$ samples were settled in Utermöhl chambers for at least $18 \mathrm{~h}$ and enumerated using light microscopy at 400x magnification with a Zeiss Axiovert S100 inverted microscope (Utermöhl, 1958). Diatoms were identified to the genus level. Total microzooplankton abundance and community composition was determined for samples preserved with $10 \%$ acid Lugol's solution (final concentration) and stored in the dark at room temperature until analysis (Throndsen, 1978). One hundred $\mathrm{mL}$ samples were settled in Utermöhl chambers for at least $18 \mathrm{~h}$ and enumerated using light microscopy at 200x magnification. Microzooplankton were identified to the genus level. The use of acid Lugol's solution obscured Chl- $a$ fluorescence and made it impossible to distinguish phototrophic from heterotrophic dinoflagellates based on autofluorescence. However, certain heterotrophic dinoflagellates such as Protoperidinium and Gyrodinium could be identified based on morphology, and were thus included in the counts.

\subsection{Dissolved and particulate nutrients and dissolved iron}

Samples for dissolved nutrients were $0.2 \mu \mathrm{m}$ filtered and immediately analyzed using a Lachat QuikChem 8000 Flow Injection Analysis System. The precision of the nutrient analyses were as follows: phosphate $0.7 \%$, nitrite $2.5 \%$, nitrate + nitrite $1.0 \%$, silicic acid $0.5 \%$. Total dissolved Fe concentrations were filtered through $0.4 \mu \mathrm{m}$ track-etched polycarbonate filters (Nuclepore Whatman) and acidified to pH 1.7 with $4 \mathrm{~mL}^{-1}$ sub-boiled distilled $\mathrm{HCl}$. Total dissolved Fe was measured using adsorptive cathodic stripping voltammetry (ACSV) (Buck et al., 2007). A $5 \mathrm{mM}$ salicylaldoxime (SA: Aldrich, $\geq 98 \%$ ) solution was first prepared in quartz-distilled methanol $(\mathrm{Q}-\mathrm{MeOH})$ and stored in the refrigerator. A final concentration of $25 \mu \mathrm{M}$ SA was used for total dissolved Fe measurements. A $1.5 \mathrm{M}$ borate buffer was made in $0.4 \mathrm{~mol} \mathrm{~L}$ quartz-distilled ammonium hydroxide $\left(\mathrm{Q}-\mathrm{NH}_{4} \mathrm{OH}\right)$ as previously described (Ellwood and Van den Berg, 2000). The voltammetric system consisted of Princeton Applied Research (PAR) 303A interfaced with a computer-controlled AutolabII potentiostat/galvanostat (Eco Chemie). The working electrode was a "large" mercury drop $\left(2.8 \mathrm{~mm}^{2}\right)$, the reference electrode was $\mathrm{Ag}$ : saturated $\mathrm{AgCl}$, saturated $\mathrm{KCl}$, and the counterelectrode was a platinum wire.

Acidified samples were microwaved $2 \times 15 \mathrm{~s}$ at $1100 \mathrm{~W}$ to release dissolved $\mathrm{Fe}$ from ambient organic ligands (Bruland et al., 2005), neutralized once with cool $1 \mathrm{~mol} \mathrm{~L}^{-1}$ $\mathrm{QNH}_{4} \mathrm{OH}$, and buffered to $\mathrm{pH} 8.2$ with the borate buffer. Once buffered, Fe and SA additions were made and following ACSV analysis Fe concentrations were determined from a linear regression of the standard addition curve. The detection limit for the ACSV method is $0.02 \mathrm{nmol} \mathrm{L}^{-1}$, calculated from three times the standard deviation of a $0.05 \mathrm{nmol} \mathrm{L}^{-1}$ $\mathrm{Fe}$ addition, as no peak is observed in either Milli-Q or ultraviolet (UV)-oxidized seawater (from which trace metals and metal-chelating organic ligands are removed from seawater; (Donat and Bruland, 1988) at deposition times of up to $600 \mathrm{~s}$. 
Deposition times for sample analyses here were between 60 and $400 \mathrm{~s}$, depending on ambient Fe concentrations. The precision of this technique for replicate samples is less than $4 \%$.

Total particulate carbon and nitrogen samples (150$250 \mathrm{~mL}$ ) were filtered at low vacuum onto GF/F filters that had been precombusted at $450^{\circ} \mathrm{C}$ for $2 \mathrm{~h}$. Filters were then dried at $60^{\circ} \mathrm{C}$. Samples were analyzed with a Finnigan Delta Plus mass spectrometer and a Carlo Erba NA1500 elemental analyzer/Conflo II. Elemental compositions were measured using the mass 44 beam intensity (V) on the Delta Plus and calibrated against the mass 44 beam intensity of at least five standards also analyzed during each run of 40 samples. Total particulate phosphorus samples $(100-200 \mathrm{~mL})$ were gently filtered onto precombusted GF/F filters and rinsed with $2 \mathrm{ml}$ $0.12 \mathrm{~mol} \mathrm{~L}^{-1} \mathrm{Na}_{2} \mathrm{SO}_{4}$. Filters were placed overnight in precombusted $\left(450^{\circ} \mathrm{C}\right.$, overnight $) 20 \mathrm{~mL}$ borosilicate glass scintillation vials with $2 \mathrm{~mL} 0.017 \mathrm{~mol} \mathrm{~L}^{-1} \mathrm{MnSO}_{4}$. Vials were covered with aluminum foil, dried at $95^{\circ} \mathrm{C}$ and stored dessicated until analysis. Total particulate phosphorus content was determined as follows: vials and filters were combusted at $450^{\circ} \mathrm{C}$ for $2 \mathrm{~h}$, cooled, and $5 \mathrm{~mL} 0.2 \mathrm{~mol} \mathrm{~L}^{-1} \mathrm{HCl}$ was added to each vial. Vials were capped and heated to $80^{\circ} \mathrm{C}$ for $30 \mathrm{~min}$ to digest particulate organic phosphorus into inorganic phosphate, and digested samples were analyzed using the standard molybdate colorimetric method (Solorzano and Sharp, 1980). Biogenic silica samples (100-250 mL) were gently filtered onto $0.6 \mu \mathrm{m}$ polycarbonate filters, dried at $60^{\circ} \mathrm{C}$ and stored at room temperature until analysis. Samples were analyzed according to Brzezinski and Nelson (1995).

\subsection{DMS/DMSP}

Samples for dimethylsulphide (DMS) and dimethylsulphoniopropionate (DMSP) were collected using the methodology of Kiene and Slezak (2006). A small volume of each sample $(\leq 15 \mathrm{~mL})$ was gravity filtered through a $25 \mathrm{~mm}$ Whatman GF/F filter and the filtrate collected for the immediate determination of DMS. A second gravity-filtered sample $(\leq 20 \mathrm{~mL})$ was collected and the filtrate preserved with $50 \%$ sulfuric acid for the determination of dissolved DMSP $\left(\mathrm{DMSP}_{\mathrm{d}}\right)$. Aliquots of the unfiltered samples $(\leq 20 \mathrm{~mL})$ were preserved with $50 \%$ sulfuric acid $(100 \mu \mathrm{L}$ per $10 \mathrm{~mL}$ of sample) for the determination of total DMSP (DMSP $)$. All DMSP samples were stored at $0^{\circ} \mathrm{C}$ until they could be analyzed, which was within three days of their collection. Upon analysis, the DMSP samples were base-hydrolyzed $\left(2 \mathrm{~mol} \mathrm{~L}^{-1}\right.$ sodium hydroxide) and measured as DMS using a cryogenic purge and trap systems coupled to either a Hewlett-Packard 5890 Series II gas chromatograph and an Agilent 6890 gas chromatograph that were fitted with flame photometric detectors (DiTullio and Smith, 1995). Both systems were calibrated using constant-temperature DMS permeation devices (Vici Metronics) and DMSP standards (Research Plus Inc). Particulate DMSP (DMSP ${ }_{p}$ ) was calculated as the difference between DMSP $_{t}$ and DMSP $_{d}$.

\subsection{Statistical analyses}

Main effects (the effect of an independent variable on a dependent variable averaging across the levels of any other independent variables) of iron and temperature individually and interactions between these two variables were compared across treatments using a modified two-way ANOVA analysis based on a percentile bootstrap method (Wilcox, 2003). This method was chosen over the classic two-way ANOVA because it does not have the assumptions of normality or homoscedasticity and generally has higher power. All tests were done at the $\alpha=0.05$ level. The statistical software program $\mathrm{R}$ version 2.5 was used to perform all tests (http://www. r-project.org). Diatom and microzooplankton communitylevel analyses were completed using multivariate statistics. The ecological statistical software program PRIMER v.6 was used to perform all multivariate analyses (Clarke and Gorley, 2006; Clarke and Warwick, 2001). A square root transformation was applied to data to slightly increase the contribution of rarer species to the measure of similarity among samples. The Bray-Curtis coefficient was used to generate the similarity matrix. Non-metric multidimensional scaling (MDS) was used to visualize high-level sample relationships in two dimensions. The relationships between individual samples based on whole communities within each were compared using this technique. Each symbol on an MDS plot represents an entire community (in this case, either diatoms or microzooplankton) from a single sample. Two samples with relatively similar assemblages (e.g., replicates from a single treatment at a single time) have symbols located very close to each other on a two-dimensional MDS plot. Two samples with relatively different communities (e.g., samples from different treatments or samples from different times) have symbols located relatively far away from each other on the same two-dimensional MDS plot. The MDS plots illustrate relative differences between samples within a group. Since the distances plotted are relative and not absolute, the axes of an MDS plot are without absolute scale. The significance of treatment effects on community composition were determined using the two-way crossed ANOSIM test (Clarke and Green, 1988). This procedure uses ranked similarities and a permutation test to compare the overall similarity of samples assigned to groups based on individual variables (iron and temperature) to the overall similarity of samples between variable groups to determine the significance level of community composition differences between variables. Microzooplankton taxa that were significant contributors to observed differences in community composition between treatments were identified using the BEST procedure in PRIMER v.6. (Clarke, 1993). 

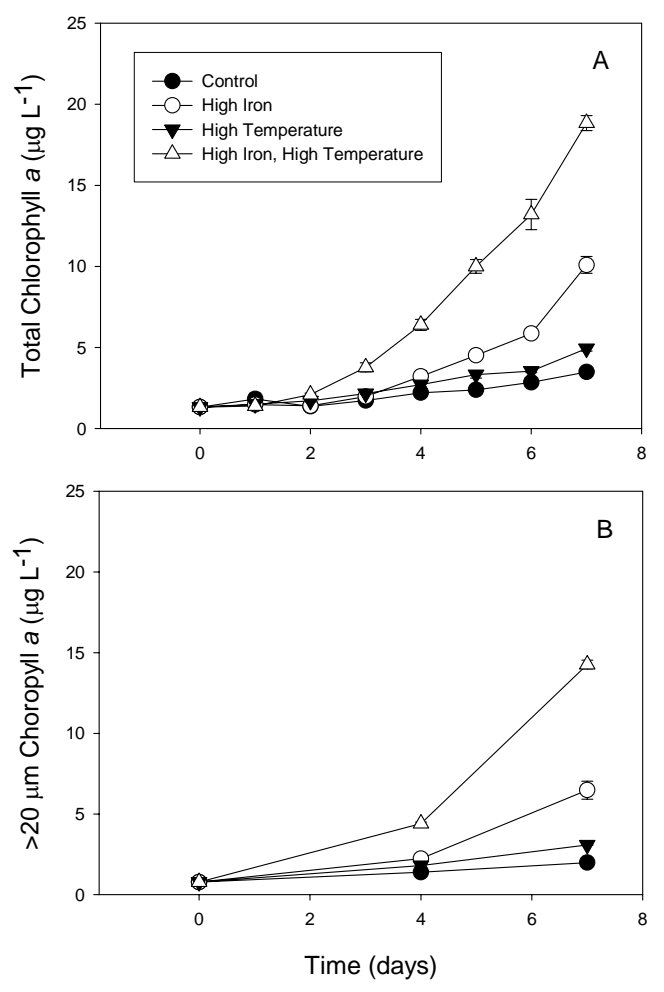

Fig. 1. Size-fractionated chlorophyll- $a$ concentrations. (A) $0.2 \mu \mathrm{m}$, total phytoplankton assemblage; (B) $>20 \mu \mathrm{m}$ size fraction. Error bars indicate one standard deviation.

\section{Results}

\subsection{Plankton assemblages}

Total chlorophyll and the $>20 \mu \mathrm{m}$ chlorophyll size fraction both increased in all treatments over the course of the experiment (Fig. 1). Final day total chlorophyll was lowest in the control treatment, higher in the high temperature treatment, and higher still in the high iron treatment. However, total chlorophyll- $a$ was by far highest in the high iron, high temperature (combined treatment) (Fig. 1a). There were significant main effects for both variables and significant interaction between both variables on the final day of the experiment (all $p<0.001$ ). On the final day of the experiment, the $>20 \mu \mathrm{m}$ size fraction constituted the majority of total chlorophyll, from $57 \%$ in the control treatment to 63 and $64 \%$ in the high temperature and iron treatments respectively, and $76 \%$ in the combined treatment (Fig. 1b).

Nanophytoplankton abundance was also significantly greater in all three experimental treatments over controls by the end of the experiment (all $p<0.001$; Fig. 2a). Both high temperature and iron treatments had significant but relatively minor main effects on nanophytoplankton abundance, and there were also significant interactions between these variables, with final abundances in the combined treatment more than double any other treatments. We also observed signifi-
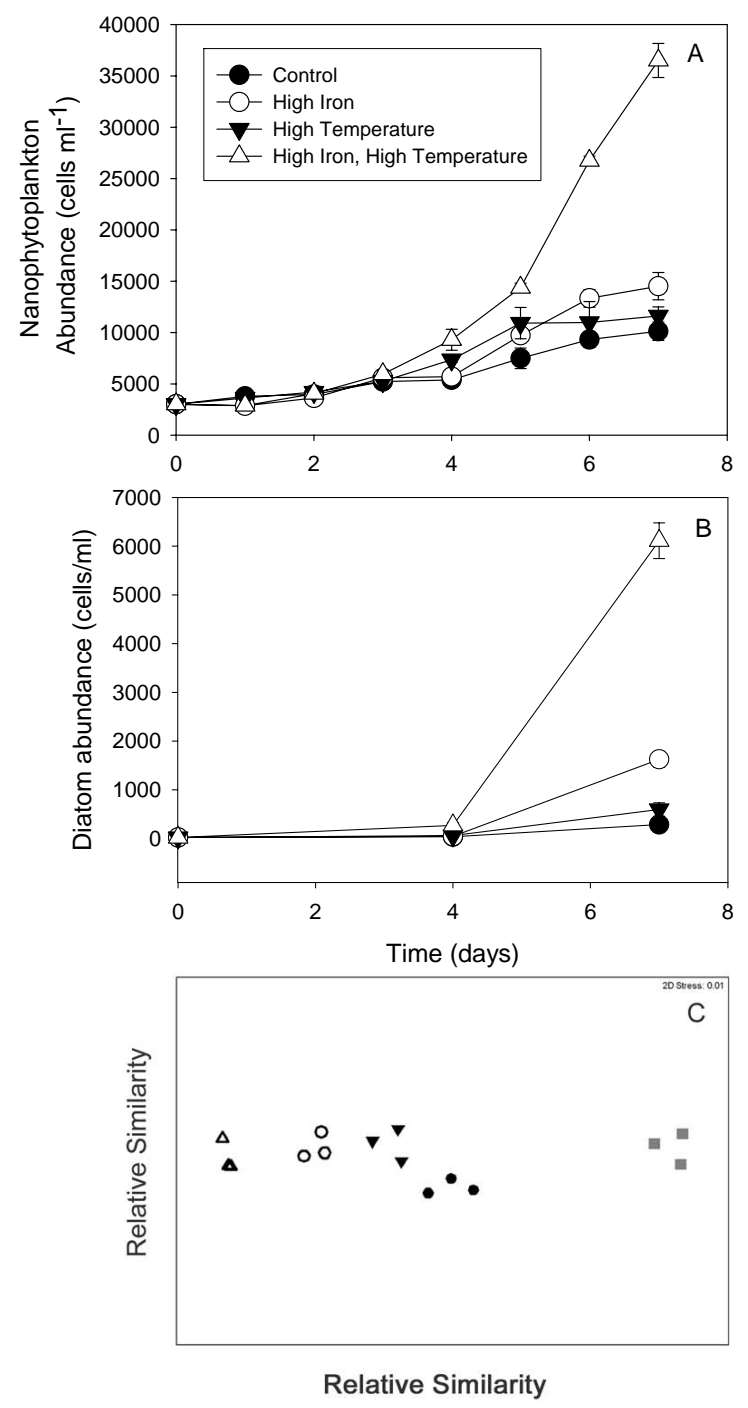

Fig. 2. Phytoplankton assemblages. (A) Nanophytoplankton abundance estimated by flow cytometry; (B) Total diatom abundance estimated by light microscopy; (C) Map of relative similarities among initial and final day diatom assemblages plotted by day and treatment using non-metric multidimensional scaling (MDS). The map illustrates relative distances between samples and thus the axes are without absolute scale. $(\square)$ Initial phytoplankton assemblages, $(\bullet)$ control, $(\boldsymbol{\nabla})$ high temperature, $(O)$ high iron and $(\triangle)$ high temperature, high iron combined treatment. Error bars indicate one standard deviation.

cant main effects for both variables and interactions between temperature and iron on total diatom abundance at the end of the experiment (Fig. 2b, $p<0.001$ ). Final diatom abundance was lowest in controls, double the control abundance in the final high temperature treatment, and more than four times the control abundance in the final high iron treatment. Final diatom abundance in the combined treatment was more than triple that of any other treatments and was more than an order of magnitude greater than the abundance observed in the final control treatment. 

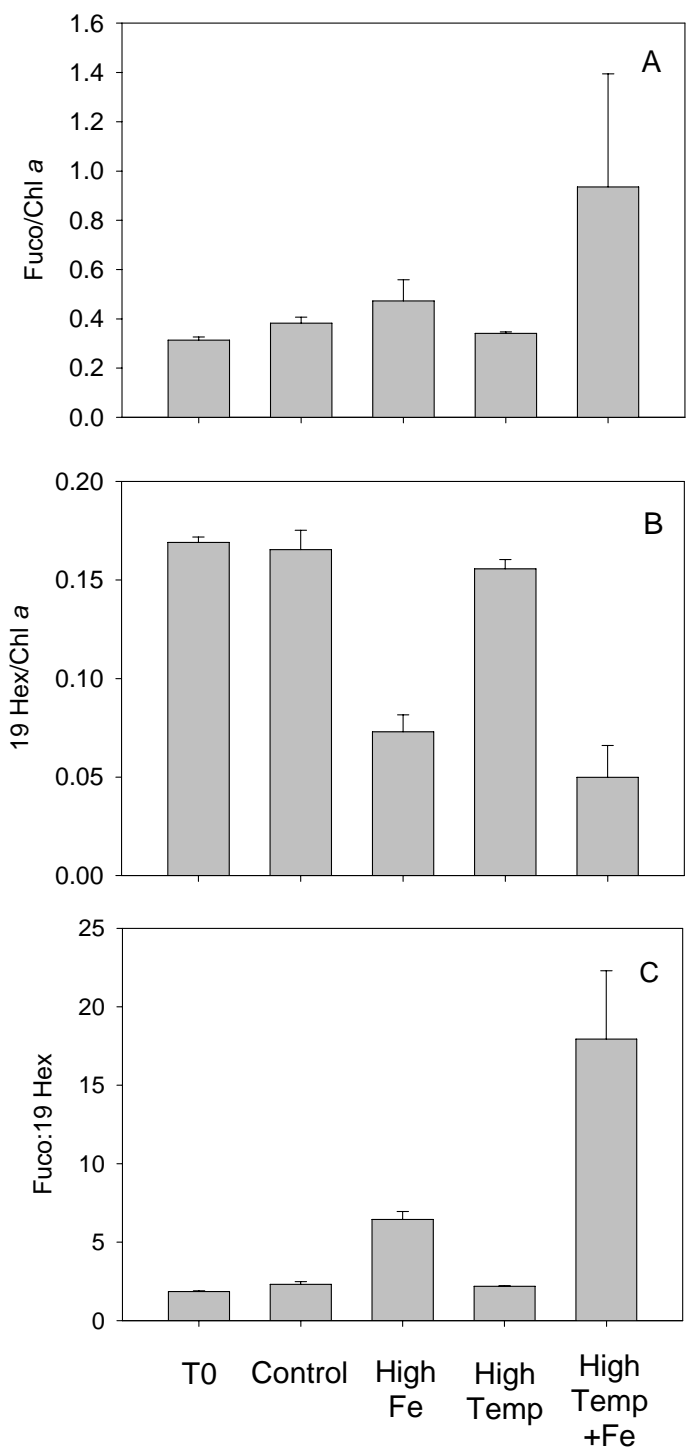

Fig. 3. Average (A) Fuco and (B) $19^{\prime}$-Hex pigment concentrations normalized to HPLC-derived chlorophyll- $a$ concentration, (C) Ratio of Fuco:19'-Hex. Error bars indicate one standard deviation.

The phytoplankton pigment data indicated that the final assemblage in all treatments was dominated by diatoms (as indicated by fucoxanthin; Fuco) rather than haptophytes such as Phaeocystis antarctica (as indicated by 19'hexanoyloxyfucoxanthin; 19-hex; Fig. 3). Final ratios of 19-hex/Chl- $a$ declined from initial values in all treatments, and only were a fraction of final Fuco concentrations (both normalized to HPLC-based chlorophyll- $a$ ). Since Fuco pigments are found in both diatoms and haptophytes (but predominantly diatoms in the Ross Sea; DiTullio et al. 2003), and 19-hex pigments are primarily indicative of haptophytes, this result suggests that the major contributors to Fuco pigments in the phytoplankton community were diatoms. Elevated Fuco: Hex ratios were measured in the two iron treat-

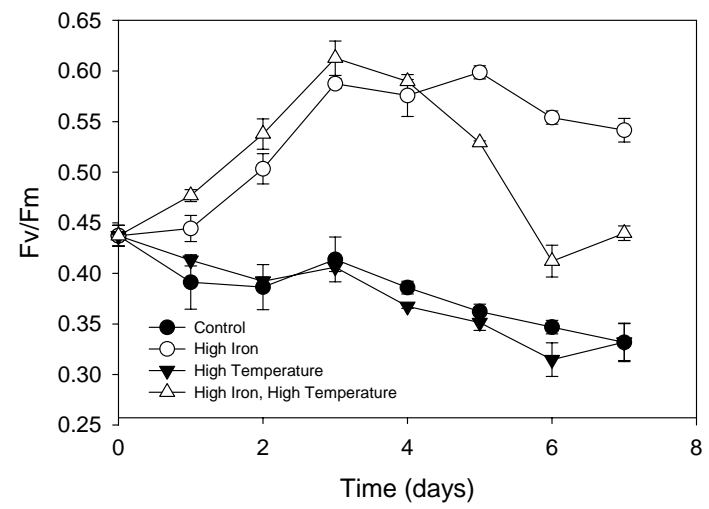

Fig. 4. Photosystem II efficiency $\left(F_{v} / F_{m}\right)$ measured over the course of the experiment in all four treatments.

ments and were consistent with the decrease in the Hex:Chl$a$ observed in those treatments (Fig. 3c). These data suggest the preferential stimulation of diatoms following Fe addition. The significant increase in the Fuco:Hex ratio in the combined treatment is corroborated by microscope-based counts of total diatom abundance (Fig. 2b). The diatom community itself changed significantly over the course of the experiment ( $p=0.01$, Fig. 2c, Table 1). Samples significantly grouped according to either iron concentration or temperature based on whole community measurements of similarity $(p=0.01)$.

Microscopic diatom cell counts showed a community shift from initial dominance by Chaetoceros sp. and Nitzschia sp., to a final assemblage largely dominated by Cylindrotheca sp. and Thalassiosira sp. in all treatments (Table 1). The large chain-forming, heavily-silicified diatoms Chaetoceros sp. and Fragilariopsis sp. were also relatively important contributors to total diatom numbers in the final samples. For all of these dominant genera, a general pattern was observed in which higher temperature alone increased their abundance significantly above the control values, and iron addition alone increased their numbers equally or even more. However, by far the highest final cell abundances for all four dominant species were seen in the combined high iron, high temperature treatment. For example, final Cylindrotheca sp. cell numbers in the combined treatment were 8,16 and 70 times higher than in the high iron, high temperature, and control treatments, respectively (Table 1).

Photosynthetic efficiency $\left(F_{v} / F_{m}\right)$ was measured on each day of the experiment and was consistently highest in the two high-iron treatments (Fig. 4). $F_{v} / F_{m}$ increased steadily from days $0-3$ from 0.44 to $\sim 0.6$ in both high iron treatments. $F_{v} / F_{m}$ remained at this level for the remainder of the experiment in the high iron treatment. In the high iron, high temperature treatment, $F_{v} / F_{m}$ peaked at day 3 and steadily declined to initial levels by the end of the experiment. The $F_{v} / F_{m}$ in both treatments without added iron slowly and consistently declined over the course of the experiment to 0.33 on the 
Table 1. Phytoplankton community composition based on microscopic counts. All values are in cells $\mathrm{mL}^{-1}$. Numbers in parentheses indicate one standard deviation.

\begin{tabular}{llllll}
\hline & T0 & Control & $\begin{array}{l}\text { High } \\
\text { Iron }\end{array}$ & $\begin{array}{l}\text { High } \\
\text { Temp }\end{array}$ & $\begin{array}{l}\text { High Iron, } \\
\text { High Temp }\end{array}$ \\
\hline Chaetoceros sp. & $5.8(0.5)$ & $100.0(26.3)$ & $101.0(17.9)$ & $99.4(21.4)$ & $309.7(102.1)$ \\
Pseudo-nitzschia sp. & $0.3(0.3)$ & $12.7(12.1)$ & $29.7(14.0)$ & $40.9(16.5)$ & $48.3(37.7)$ \\
Corethron sp. & $2.8(1.3)$ & $21.4(3.2)$ & $22.3(4.9)$ & $21.7(10.4)$ & $39.6(17.6)$ \\
Fragilariopsis sp. & $3.2(1.7)$ & $66.6(22.4)$ & $157.3(15.1)$ & $87.9(23.5)$ & $365.4(86.4)$ \\
Coscinodiscus sp. & $0.3(0.4)$ & $1.5(1.1)$ & $1.9(3.2)$ & $3.1(1.4)$ & $1.2(2.1)$ \\
Nitzschia sp. & $7.8(3.3)$ & $21.4(10.7)$ & $22.3(6.7)$ & $18.6(4.8)$ & $19.8(11.4)$ \\
Rhizosolenia sp. & $0.3(0.2)$ & $2.2(1.1)$ & $5.6(3.2)$ & $2.5(0.5)$ & $7.4(3.7)$ \\
Cylindrotheca sp. & $0.4(0.1)$ & $61.0(33.3)$ & $502.3(117.5)$ & $269.7(81.8)$ & $4261.1(262.2)$ \\
Silicoflagellate sp. & $0.2(0.1)$ & 0.0 & $0.6(1.1)$ & $2.2(0.5)$ & $1.2(2.1)$ \\
Thalassiosira sp. & 0.0 & $0.9(1.6)$ & $782.2(35.9)$ & $49.9(12.3)$ & $1056.6(113.6)$ \\
Asteromphalus sp. & 0.0 & $0.3(0.5)$ & $0.6(1.1)$ & $1.5(2.7)$ & $1.2(2.1)$ \\
\hline
\end{tabular}

final day. The effects of temperature and iron individually as well as the interaction between these two variables were significant on the final day of the experiment (all $p<0.001$ ).

Microzooplankton abundance followed different trends than those observed for the phytoplankton community (Fig. 5a). Final microzooplankton abundance was higher in the two low-iron treatments, with the highest abundance observed in the high temperature treatment. Microzooplankton abundances declined between the beginning of the experiment and day 4 in the two high-iron treatments, and ended significantly lower when compared to the two low-iron treatments $(p<0.001)$. All main effects and interactions for microzooplankton abundance were significant on the final day of the experiment $(p<0.001)$. Microzooplankton community composition was also significantly different across the four treatments (Fig. 5b, Table 2). Microzooplankton communities grouped significantly according to both temperature and iron (both $p=0.01$ ), indicating that communities at different temperatures and communities exposed to different iron concentrations were significantly different in their composition. Six microzooplankton taxa were identified as being important contributors to observed changes in community composition: Oxyphysis sp., Protoperidinium sp., Gyrodinium sp., Litonotus sp. and two species of scuticociliate (Table 2).

\subsection{Dissolved and particulate nutrients}

Dissolved nutrient concentrations declined with increased phytoplankton biomass in all treatments over the course of the experiment (Fig. 6). The greatest decreases in $\mathrm{NO}_{3}^{-}$, $\mathrm{PO}_{4}^{3-}$ and $\mathrm{SiOH}_{4}$ all occurred in the combined treatment by the final day of the experiment. There were significant main effects and interactions for temperature and iron on all three final day dissolved nutrient concentrations $(p<0.001)$. Total dissolved iron concentrations were considerably lower
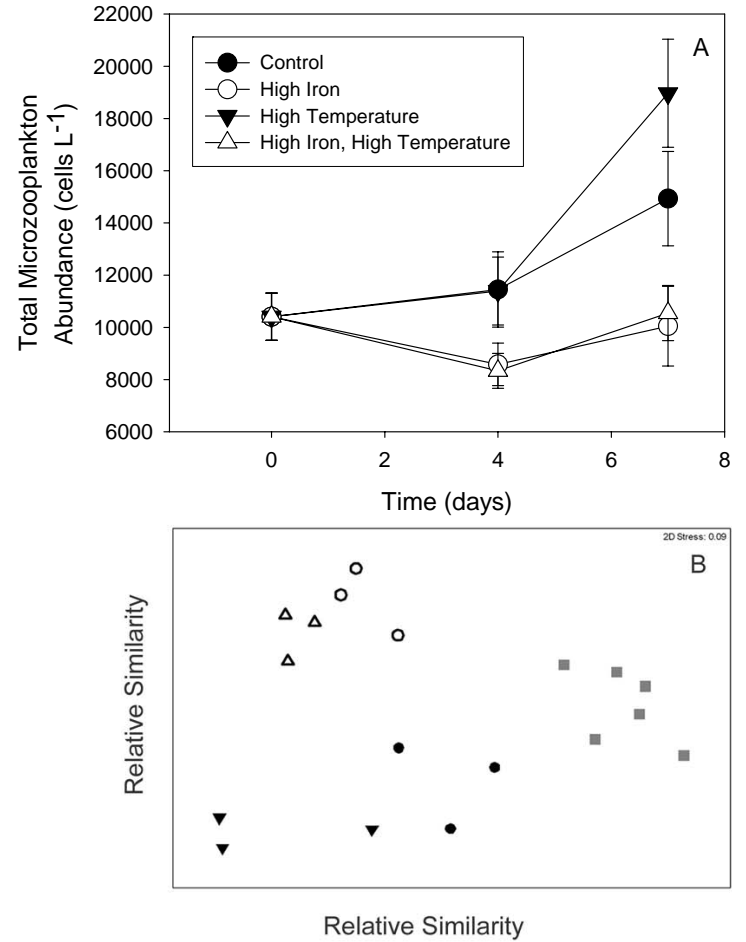

Fig. 5. Microzooplankton abundance and community composition. (A) Total abundance of microzooplankton over the course of the experiment. Error bars indicate one standard deviation. (B) MDS plot of relative similarities among initial and final day microzooplankton assemblages. ( $\square)$ Initial microzooplankton assemblages, $(\bullet)$ control, $(\boldsymbol{\nabla})$ high temperature, $(O)$ high iron and $(\triangle)$ high temperature, high iron combined treatment. 

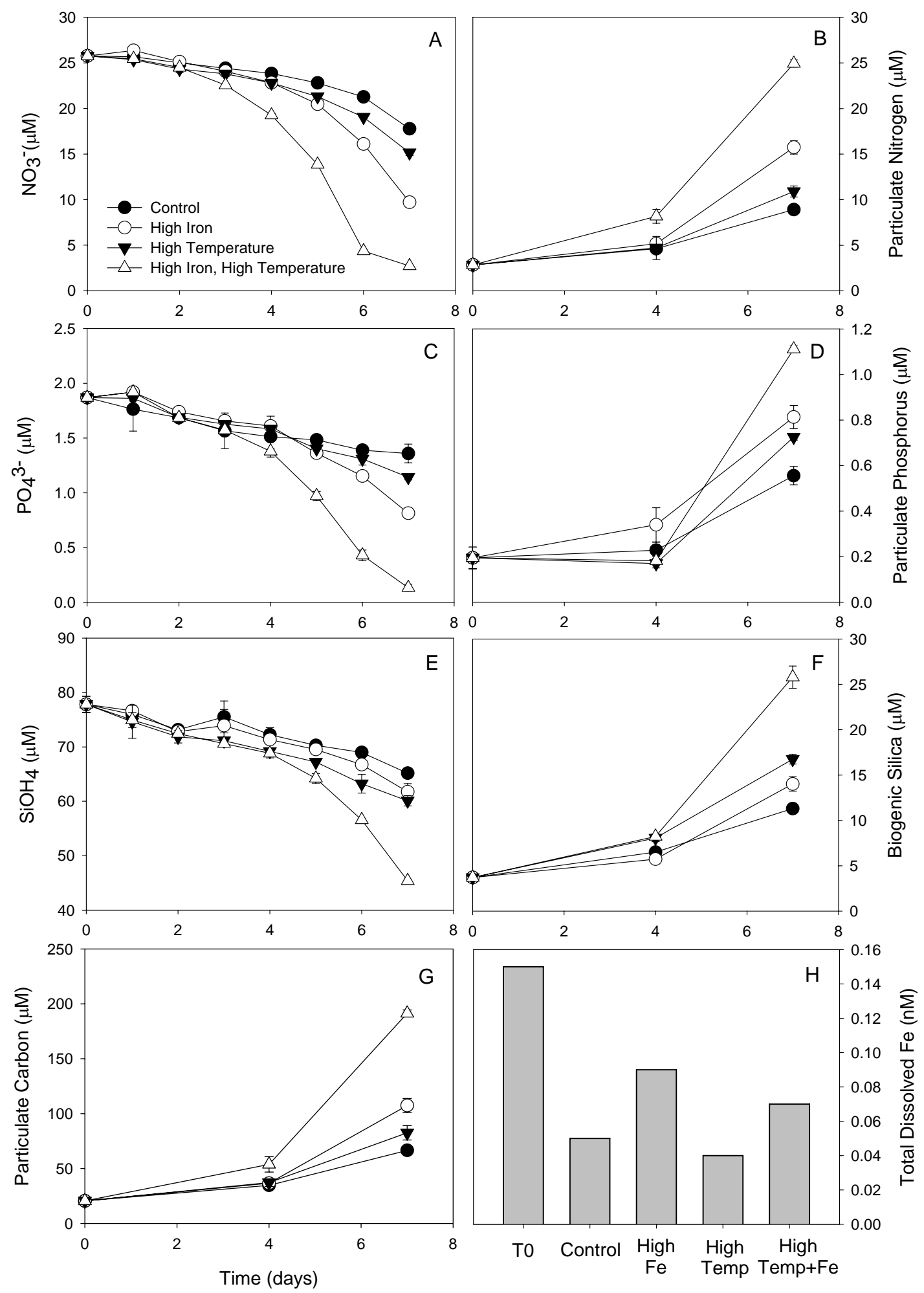

Fig. 6. Dissolved and particulate nutrient concentrations over the course of the experiment. (A) $\mathrm{NO}_{3}^{-}$, (B) Particulate nitrogen, $(\mathbf{C}) \mathrm{PO}_{4}^{3-}$, (D) Particulate phosphorus, (E) $\mathrm{SiOH}_{4}$, (F) Biogenic silica, (G) Particulate carbon, (H) Total dissolved iron. Error bars in (A-G) indicate one standard deviation. 
Table 2. Initial and final day microzooplankton community composition based on microscopic counts. All values are in cells $\mathrm{L}^{-1}$. Numbers in parentheses indicate one standard deviation. Taxa that were identified as important contributors to community composition by the BEST procedure (PRIMER v.6) are highlighted in bold.

\begin{tabular}{llllll}
\hline & T0 & Control & $\begin{array}{l}\text { High } \\
\text { Iron }\end{array}$ & $\begin{array}{l}\text { High } \\
\text { Temp }\end{array}$ & $\begin{array}{l}\text { High Iron, } \\
\text { High Temp }\end{array}$ \\
\hline Codonellopsis sp. & $175(55)$ & $50(10)$ & $3(6)$ & $7(12)$ & $3(6)$ \\
Cymatocylis sp. & $22(8)$ & $50(17)$ & $13(15)$ & $17(12)$ & $3(6)$ \\
Coxliella sp. & $23(23)$ & $10(10)$ & 0 & 0 & 0 \\
Didinium sp. & $28(15)$ & $3(6)$ & $3(6)$ & 0 & $3(6)$ \\
Strombidium sp. & $1485(510)$ & $1110(319)$ & $785(160)$ & $1614(766)$ & $1857(791)$ \\
Protoperidinium sp. 1 & $387(118)$ & $153(162)$ & $136(32)$ & $165(285)$ & $191(65)$ \\
Gyrodinium sp. 1 & $1024(380)$ & $602(182)$ & $613(167)$ & $506(330)$ & $433(174)$ \\
Oxyphysis sp. & $2853(368)$ & $3794(340)$ & $2731(408)$ & $6234(1618)$ & $2983(416)$ \\
Scuticociliate sp. 1 & $436(135)$ & $209(181)$ & $42(72)$ & $58(101)$ & 0 \\
Eutinntinnus sp. & $926(221)$ & $1767(373)$ & $1337(416)$ & $2232(132)$ & $1938(75)$ \\
Katodinium sp. & $810(159)$ & $976(335)$ & $911(733)$ & $1018(369)$ & $509(258)$ \\
Protoperidinium sp. 2 & $1366(608)$ & $4054(574)$ & $2295(299)$ & $6515(1616)$ & $2813(396)$ \\
Gyrodinium sp. 2 & $401(220)$ & $441(112)$ & $70(64)$ & $148(131)$ & 0 \\
Scuticociliate sp. $\mathbf{2}$ & $320(164)$ & $99(87)$ & 0 & $58(101)$ & 0 \\
Litonotus sp. & $153(136)$ & $155(152)$ & 0 & 0 & 0 \\
\hline
\end{tabular}

Table 3. Average production ratios calculated based on initial and final particulate nutrient concentrations and p-values obtained from the modified two-way ANOVA analysis. Numbers in parentheses indicate one standard deviation.

\begin{tabular}{lccccccc}
\hline Control & $\begin{array}{c}\text { High } \\
\text { Iron }\end{array}$ & $\begin{array}{c}\text { High } \\
\text { Temp }\end{array}$ & $\begin{array}{c}\text { High Iron, } \\
\text { High Temp }\end{array}$ & $\begin{array}{c}\text { Main } \\
\text { Effect Iron }\end{array}$ & $\begin{array}{c}\text { Main } \\
\text { Effect Temp }\end{array}$ & Interaction \\
\hline$\triangle$ POC/PON & $7.58(0.22)$ & $6.72(0.12)$ & $7.69(0.23)$ & $7.73(0.05)$ & $<0.001$ & $<0.001$ & $<0.001$ \\
$\triangle$ POC/POP & $128(14.8)$ & $141(6.6)$ & $117(9.3)$ & $186(5.6)$ & $<0.001$ & 0.11 & $<0.001$ \\
$\triangle$ PON/POP & $17.0(2.34)$ & $20.9(1.12)$ & $15.2(0.76)$ & $24.1(0.77)$ & $<0.001$ & 0.68 & $<0.001$ \\
$\triangle$ BSi/POC & $0.17(0.01)$ & $0.12(0.00)$ & $0.21(0.01)$ & $0.13(0.01)$ & $<0.001$ & $<0.001$ & $<0.001$ \\
$\triangle$ BSi/PON & $1.25(0.06)$ & $0.80(0.04)$ & $1.62(0.02)$ & $1.00(0.06)$ & $<0.001$ & $<0.001$ & $<0.001$ \\
$\triangle \mathrm{BSi} / \mathrm{POP}$ & $21.1(1.86)$ & $16.7(0.40)$ & $24.6(0.39)$ & $24.1(1.11)$ & $<0.001$ & $<0.001$ & $<0.001$ \\
\hline
\end{tabular}

in all treatments on the final day of the experiment than on the initial day, including the two treatments enriched with $1 \mathrm{nM}$ iron at the beginning of the experiment (Fig. 6h). Final dissolved iron concentrations were lower in the control and high temperature treatments than the high iron and combined treatments, but since replicates were combined to obtain sufficient volume for the measurements, we were unable to determine if these differences were significant. The largest increases in particulate nutrient concentrations consistently occurred in the combined treatment, although effects of single factors were also significant $(p<0.001)$. There was a discrepancy between the amount of phosphate drawdown and particulate organic phosphorus production in all treatments. This result may have been due to production of dissolved organic phosphorus, which was not measured in the experiment. Interactive effects of temperature and iron were significant for all four particulate nutrients (carbon, nitrogen, phosphorus and biogenic silica).
Average production ratios were calculated for each treatment based on initial and final nutrient concentrations (Table 3). There were significant main effects observed for iron and significant interactions between variables observed for all production ratios calculated $(p<0001)$. The $\mathrm{C}: \mathrm{P}$ and $\mathrm{N}: \mathrm{P}$ ratios were significantly higher in the two treatments with added iron, especially the combined treatment $(p<0.001)$. $\mathrm{BSi}: \mathrm{C}$ and $\mathrm{BSi}: \mathrm{N}$ ratios on the other hand were higher in the two treatments without iron, especially the high temperature treatment $(p<0.001)$. C:N and BSi:P ratios were similar in all the treatments but slightly lower in the high iron bottles. Significant interactive effects were observed for all ratios calculated (all $p<0.001$ ). 

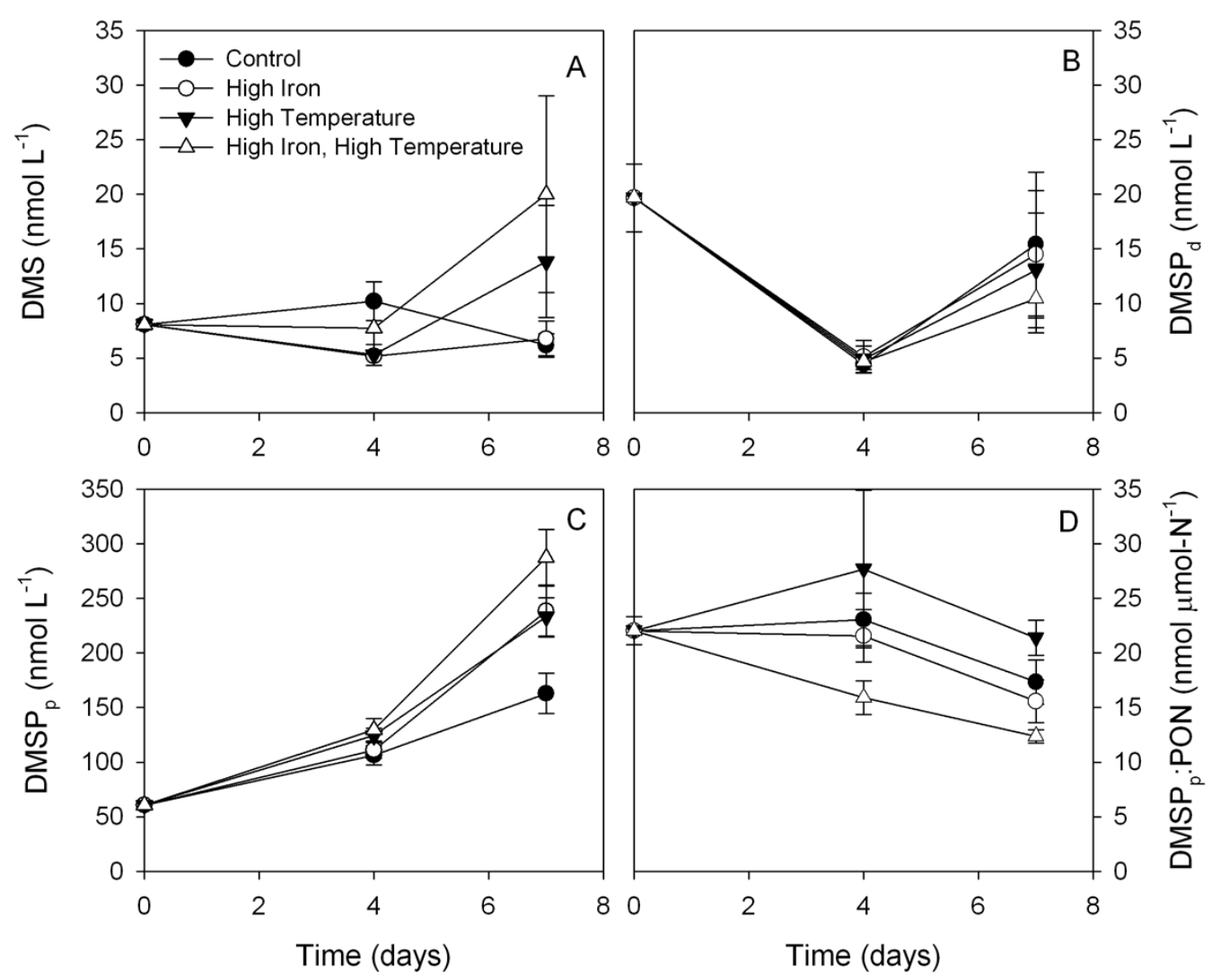

Fig. 7. Biogenic sulfur parameters over the course of the experiment. Average values for (A) DMS, $(\mathbf{B}) \mathrm{DMSP}_{\mathrm{d}}$, $(\mathbf{C}) \mathrm{DMSP}_{\mathrm{p}}$, and $(\mathbf{D})$ $\mathrm{DMSP}_{\mathrm{p}}: \mathrm{PON}$. Error bars indicate one standard deviation.

\subsection{Dimethylsulfide and dimethylsulfoniopropionate}

DMS concentrations showed only relatively small changes between the start of the experiment and day 4. By the final day, DMS levels in the high temperature and combined treatments were approximately 3- and 4-fold higher than the control (Fig. 7a). Individually, both variables had a significant effect on DMS levels on the final day and a significant interactive effect between the two variables was also observed (all $p<0.001$ ). DMSP $\mathrm{d}_{\mathrm{d}}$ levels in all treatments were slightly lower at the end of the experiment than the initial concentration, with the combined treatment showing the greatest decline followed by the high temperature treatment (Fig. 7b). However, none of the changes in $\mathrm{DMSP}_{\mathrm{d}}$ concentrations were significant.

DMSP $_{\mathrm{p}}$ concentrations increased throughout the course of the incubation with largest increases observed between days 4 and 7 (Fig. $7 \mathrm{c}$ ). DMSP $_{\mathrm{p}}$ levels were highest in the combined treatment followed by high iron and high temperature treatments. In all cases, the changes in the variables had significant effects $(p<0.001)$ on DMSP $_{\mathrm{p}}$ levels both individually and synergistically. With respect to $\mathrm{DMSP}_{\mathrm{p}}$ :Chl$a$ ratios, while no change was observed in the control or high temperature treatments relative to starting conditions (Fig. 7d), there was a significant decrease in the high iron treatment and a synergistic decrease in the combined treatment on the final day (both $p<0.001$ ). In the case of $\mathrm{DMSP}_{\mathrm{p}}: \mathrm{PON}$ ratios, values in the high temperature treatment were higher than control on both sampling days although temperature had no significant effect (Fig. 7e). Conversely, the addition of iron caused a significant decline $(p<0.001)$ in $\mathrm{DMSP}_{\mathrm{p}}: \mathrm{PON}$ ratios, with a significantly higher decrease observed in the high temperature treatment when normalized to PON.

A recent study (Kiene et al., 2007) has noted that samples preserved using the Kiene and Slezak (2006) method can underestimate $\mathrm{DMSP}_{\mathrm{t}}$ when Phaeocystis sp. is present. Although it is not known quantitatively by how much the DMSP $_{\mathrm{p}}$ levels will be underestimated (del Valle et al., 2009; Rellinger et al., 2009), this finding could impact the $\mathrm{DMSP}_{\mathrm{p}}$ results obtained during the experiment. While the phytoplankton community was dominated by diatoms and addition of iron caused the dominance of diatoms to increase (Fig. 3), the differences in $\mathrm{DMSP}_{\mathrm{p}}$ concentrations cannot be considered significant as a result of presence of even a minor amount of Phaeocystis sp. This underestimation will also result in an underestimation of the decreases in $\mathrm{DMSP}_{\mathrm{p}}$ :Chl$a$ and DMSP $_{\mathrm{p}}: \mathrm{PON}$ ratios. Moreover, the observed trends in DMS and DMSP $_{d}$ also remain robust since these two parameters are unaffected by the preservation problem. 


\section{Conclusions}

Previous studies of interactive effects of iron limitation with other factors influencing phytoplankton assemblages have focused largely on co-limitation effects with macro- and micronutrients (Bertrand et al., 2007; Leblanc et al., 2005) or light intensity (Boyd et al., 2001; Sunda and Huntsman, 1997). Temperature has also been recognized to play an important role in setting upper limits on physiological rate processes in plankton (Eppley, 1972; Goldman and Carpenter, 1974), and the interactions of temperature with other environmental variables such as rising $p \mathrm{CO}_{2}$, altered irradiance and nutrient utilization have been examined in a few field and lab studies (Feng et al., 2009; Goldman, 1979; Hare et al., 2007; Lomas and Glibert, 1999; Rose et al., 2009). Temperature has also been hypothesized to constrain growth of heterotrophic protists relative to phototrophic protists at the extreme low temperatures characteristic of polar regions (Rose and Caron, 2007).

Warmer temperatures have been shown to cause large dominance shifts in experimentally manipulated plankton communities from other high-latitude regimes such as the Bering Sea and the North Atlantic (Feng et al., 2009; Hare et al., 2007; Noiri et al., 2005; Rose et al., 2009). The combination of increased iron and temperature was observed to result in shifts in phytoplankton community composition during the SEEDS study in the western subarctic Pacific, but only at the highest temperature examined $\left(18^{\circ} \mathrm{C}\right.$; Noiri et al., 2005). Noiri et al. (2005) did not report interactive effects of temperature and iron on other physiological and biochemical factors, and did not examine potential changes in food web dynamics during their experiments.

We consistently observed nonlinear, synergistic effects of iron and temperature on phytoplankton abundance, phytoplankton physiology and nutrient drawdown in our experiments. These enhancement effects of both variables together were much greater than simply additive, and so could not have been predicted based on the effects of temperature and iron measured individually. The increase in nanophytoplankton abundance in the high iron, high temperature treatment was more than double the increase in either the high iron or high temperature treatments, and greater than the additive effects of those single-variable treatments combined. Similar results for total diatom abundance were observed, with the final day abundance in the high temperature, high iron treatment again far exceeding the additive effects of the two variables examined individually.

Increased temperature at high iron concentration appeared to also bring on nutrient limitation earlier in the experiment. $F_{v} / F_{m}$ values were nearly identical for both high-iron treatments during the initial days of the experiment and rapidly increased to $\sim 0.6$ which is expected upon alleviation of iron limitation (Green et al., 1994). However, the high iron, high temperature treatment peaked on day 3 and consistently decreased for the remainder of the experiment. Since phyto- plankton growth rates generally increase with increased temperatures, the early $F_{v} / F_{m}$ peak and decline was most likely due to the more rapid utilization of added iron and the earlier onset of iron limitation. This trend was not observed when temperatures were increased in the absence of iron addition; decreases in $F_{v} / F_{m}$ in the high temperature treatment occurred at a nearly identical rate as those in the control treatment.

Determination of the exact physiological mechanisms responsible for these non-linear impacts of combined iron increases and warming will require further investigation. In general though, physiological iron/temperature synergisms should perhaps not be surprising. Iron plays a central role in many cellular catalytic reactions involved in pathways like photosynthesis and nitrogen assimilation (Hutchins and $\mathrm{Fu}, 2008$ ), and many of these enzymatic reactions also have a recognized sensitivity to temperature (Raven and Geider, 1988). Since both iron availability and temperature are critical controls on many of the same biochemical pathways, iron/temperature "co-limitation" may be a common physiological feature of marine phytoplankton.

Our observations of iron stimulation of phytoplankton abundance and photosynthetic rates, as well as growth of large diatoms relative to other phytoplankton taxa, are consistent with previous results for bottle incubations and iron enrichment in polar waters with high silicic acid concentrations. Several mesoscale iron enrichment experiments have been conducted in Southern Ocean waters to date (Boyd et al., 2000; Coale et al., 2004; Gervais et al., 2002). An immediate stimulation of $F_{v} / F_{m}$ followed by a time-lagged increase in chlorophyll- $a$ was observed during all three Antarctic iron enrichment experiments (SOIREE, EisenEx and the SoFex high-Si south patch). A taxonomic shift to large (microplankton-sized) diatoms was observed during SOIREE. During EisenEx and the SoFex south patch, the initial community dominance by diatoms was unchanged by the addition of iron, although authors noted that high iron concentrations in EisenEx favored growth of microphytoplankton relative to nano- and picophytoplankton assemblages.

Our study also points to the possibility of interactive effects of iron and temperature on plankton community elemental stoichiometry (Fig. 6). These suggest that patterns and ratios of nutrient drawdown in the future Ross Sea could be altered by changes in both iron supply and temperature, in addition to other recognized factors such as shifts in dominant taxa (Arrigo et al., 1999). Additionally, both iron and temperature had individual effects on community stoichiometry. For instance, the decrease in Si:N uptake ratios observed in the south patch during SoFeX (Coale et al., 2004) was similar to results for the high iron treatments obtained in our study. Similar trends have also been observed in other Southern Ocean in situ fertilization experiments (Boyd et al., 2000) as well as in other Fe-limited ecosystems (Hutchins and Bruland, 1998). 
Bulk community measurements such as ours cannot distinguish between physiologically-driven shifts in the elemental ratios of individual species, and stoichiometry changes due to taxonomic shifts in the community, but both are possible. Diatom cellular $\mathrm{Si}$ quotas have been shown to be inversely related to nutrient-limited growth rates (Martin-Jezequel et al., 2000), such as the Fe-limited conditions found in our control treatments. Using single cell synchrotron X-ray fluorescence analyses, Twining et al. (2004) showed that Fe-induced decreases in Si:P ratios of the dominant diatom Fragilariopsis spp. were due to reduced cellular Si quotas following the first Fe enrichment of the south patch during SoFex. Following the second $\mathrm{Fe}$ infusion, cellular Si:P ratios of the same species were still lower than in the unfertilized control region, but this was now due to increased cellular P quotas and unchanged Si content. Clearly, the nature of the relationship between cellular silicification and iron availability is complex (Bucciarelli et al., 2009), and needs further investigation.

In our experiment increasing temperature alone appeared to result in more heavily silicified diatom cells, with significant increases observed in BSi:C, BSi:N and BSi:P. Additionally, greater $\mathrm{Si}$ drawdown and BSi production were observed in the high temperature treatment relative to the high iron treatment, although both total chlorophyll and total diatom abundance were lower. This may have been a direct response to temperature and could indicate that warming of the Ross Sea in the absence of iron supply may lead to increased silica drawdown. Blank et al. (1986) found that $\mathrm{Si}$ incorporation increased 7.5 times over a $10^{\circ} \mathrm{C}$ increase in temperature in the diatom Navicula saprophilia. In contrast though, Paasche (1980) showed that cellular Si quotas in two species of Chaetoceros and Rhizosolenia decreased at higher temperatures. Increases in silicic acid uptake rates with temperature would make sense, if uptake is mediated mainly by active enzymatic transport. However, recent evidence suggests that at very high silicic acid concentrations $(>30 \mu \mathrm{M})$ such as those in the Ross Sea, diatoms instead shift to a nonsaturable, diffusion-mediated uptake system (Thamatrakoln and Hildebrand, 2008). Diffusion rates would be expected to be much less affected by temperature increases than active biological transport. In our experiment initial silicic acid levels were near $80 \mu \mathrm{M}$, and final concentrations were not less than $45 \mu \mathrm{M}$ in any treatment, suggesting that temperatureenhanced active uptake of silicic acid was probably not the reason for the greater degree of silicification in the warmer treatments.

Higher cellular Si quotas at elevated temperature could have also been an indirect response to increased microzooplankton grazing. Microzooplankton abundances were highest in the high temperature treatment by the end of the experiment. Increased diatom cell wall silicification in response to grazing pressure has been documented in the laboratory (Pondaven et al., 2007), but not to our knowledge in natural plankton assemblages.
Similarly, the results of this study point to changes in the cycling of DMSP and DMS as result of increases in either iron or temperature, and more critically, a synergistic effect due to both iron and temperature. The observed increases in DMSP $_{\mathrm{p}}$ most likely resulted from increases in biomass since the phytoplankton community structure showed shifts towards increased diatom dominance (or a decrease in DMSPproducing species). While the declines in $\mathrm{DMSP}_{\mathrm{p}}: \mathrm{Chl}-a$ and DMSP $_{\mathrm{p}}$ :PON ratios also reflect this shift, it must be remembered that addition of iron would affect all three parameters individually. It would decrease $\operatorname{DMSP}_{\mathrm{p}}$ due to a reduction in oxidative stress, alleviate any chlorosis that would result from iron limitation, and increase nitrogen uptake (Allen et al., 2008; Sunda et al., 2002).

Although increasing iron and temperature caused a slight decline in DMSP $_{d}$ levels, those changes were quantitatively equivalent to the observed increases in DMS. This observation suggests that the degradation of DMSP and, more importantly, the relative importance of the DMS versus nonDMS producing pathways will be affected by changing iron and temperature regimes in a complex non-linear manner. The changes in the both phytoplankton and microzooplankton communities seen during the experiment will influence changes in predator-prey interactions and the DMSP cycle (Strom et al., 2003; Wolfe and Steinke, 1996; Wolfe et al., 1997) as will variations in the presence of the DMSP-lyase (either microbial or in Phaeocystis sp.). Finally, although uncertainities exist as to whether increasing $p \mathrm{CO}_{2}$ will influence DMS (Vogt et al., 2008; Wingenter et al., 2007), the results of this experiment clearly show that increases in iron and temperature will have an important impact on any climate feedback mechanism involving DMS.

The large changes in the microzooplankton community in our experiments were somewhat unexpected. Boyd et al. (2000) reported that ciliate abundances increased after iron enrichment during SOIREE, but that microzooplankton herbivory was primarily focused on the $<20 \mu \mathrm{m}$ size fraction. These authors suggested that microzooplankton were unable to effectively graze the large Fragilariopsis kerguelenis that was favored at high iron concentrations. A similar result was reported for EisenEx, in which microzooplankton herbivory was focused on the pico- and nanophytoplankton size fractions and the overall trophic dynamics in the iron fertilization patch were believed to favor the growth of large diatoms (Henjes et al., 2007). Rates of microzooplankton herbivory have not been reported for SoFex. The exclusion of mesozooplankton grazers in our bottle incubations would be expected to significantly affect planktonic community structure. Removal of mesozooplankton could reduce top-down controls on larger microzooplankton, which would increase grazing pressure on smaller microzooplankton and heterotrophic flagellates. This type of trophic cascade was reported for EisenEx, during which initial increases in aplastidic dinoflagellates inside the fertilized patch were eventually consumed by copepods (Henjes et al., 2007). We 
do not have detailed information on microzooplankton size distribution in our treatments but did group our counts into $<100 \mu \mathrm{m}$ and $>100 \mu \mathrm{m}$ size classes. We observed decreased abundance of large $(>100 \mu \mathrm{m})$ microzooplankton in all treatments between the initial and final days of the experiment (data not shown), suggesting that removal of mesozooplankton grazers during our pre-screening process did not result in net benefits to this portion of the community.

It is unlikely that the initial decreases in microzooplankton abundance in the high iron treatments were due to direct inhibition of microzooplankton growth by elevated iron concentrations. The amount of iron added to these experiments was modest, and far below any conceivable toxicity threshold. Iron concentrations greater than $1 \mathrm{nM}$ can occasionally occur naturally in the upper water column of the Ross Sea during ice melt in early spring (Sedwick and DiTullio, 1997). Additionally, the work by Twining et al. $(2004,2008)$ has suggested that cellular iron requirements are significantly higher for heterotrophic protists than for autotrophic protists. Based on those results, a beneficial direct effect of iron addition on the heterotrophic protistan assemblage could have been expected in our experiment instead of a negative one. Instead, it seems more likely that the large changes in the diatom community composition observed over the course of the experiment resulted in an algal assemblage that was less able to be grazed by the initial microzooplankton community. The diatom communities in both low iron treatments remained diverse relative to the high iron treatments (Table 1). The communities in the high iron treatments shifted from dominance by Nitzschia sp. and Chaetoceros sp. to Thalassiosira sp. in the high iron treatment and Cylindrotheca sp. in the high iron, high temperature treatment. In particular, the very long and narrow morphology of the Cylindrotheca may have been unpalatable to microzooplankton.

The microzooplankton assemblage at the beginning of the experiment was relatively diverse, but dominated by small heterotrophic dinoflagellates such as Oxyphysis sp. and small species $(\sim 20 \mu \mathrm{m})$ within the genera Protoperidinium and Gyrodinium (Table 2). Heterotrophic dinoflagellates such as Protoperidinium are capable of feeding on phytoplankton much larger than themselves using structures such as the pallium (Jacobson and Anderson, 1986), and these species may have been actively feeding on the Nitzschia sp. and Chaetoceros sp. that dominated the phytoplankton assemblage initially.
This experiment was conducted during austral summer, with a diatom-dominated phytoplankton community that was likely post-spring bloom. The community response to increased iron and temperature would likely have been affected by the season in which the experiment was performed. For example, if the experiment had been conducted in early spring, ambient iron concentrations may have been higher (Sedwick et al., 2000), which could have resulted in a more iron-replete initial community and the effects of iron additions may have been lessened. At the same time, if the work had been conducted in early spring, ambient sea surface temperature would have been lower and the effect of increased temperature may have been greater. Additionally, the early spring phytoplankton community in the Ross Sea is generally dominated by Phaeocystis antarctica rather than diatoms. We observed different effects of iron in particular on the P. antarctica and diatom fractions of the community (Fig. 3a, b), suggesting that results observed for a community dominated by $P$. antarctica may have been very different.

The effects of increased $p \mathrm{CO}_{2}$ and temperature on polar ecosystems have been a major focus of research to date, but it is important to remember that other physicochemical factors are also predicted to be affected by a changing climate. The likelihood of changes in iron concentrations in combination with increased temperature highlights the importance of multivariate experiments to identify potential interactive effects of multiple changing factors on future plankton assemblages. The experiments detailed here are an important first step in examining the potential interactive effects of temperature and iron concentration on phytoplankton assemblages in the Ross Sea, Antarctica. The difference in the time scales for bioassays and climate change limits the extent to which bioassays can be predictive. However, it is clear from our results that without concomitant increases in iron inputs, increased temperature alone may have a smaller effect on phytoplankton assemblages. Finally, the potential interactive effects of temperature and iron together indicate that relatively small inputs of iron could disproportionately benefit plankton assemblages growing in a warmer future coastal Antarctic ecosystem.

Acknowledgements. This project was supported by US NSF grants ANT 0528715 to JMR, ANT 0741411, ANT 0741428 and OCE 0825319 to DAH, ANT 0338157 to WOS, ANT 0338097 to GRD, and ANT 0338350 to RBD. The authors would like to thank Zbigniew Kolber for providing the bench-top MBARI Fast Repetition Rate Fluorometer.

Edited by: U. Riebesell 


\section{References}

Allen, A. E., LaRoche, J., Maheswari, U., Lommer, M., Schauer, N., Lopez, P. J., Finazzi, G., Fernie, A. R., and Bowler, C.: Whole-cell response of the pennate diatom Phaeodactylum tricornutum to iron starvation, Proc Natl Acad Sci USA, 105, 10438-10443, 2008.

Alley, R., Berntsen, T., Bindoff, N. L., Chen, Z., Chidthaisong, A., Friedlingstein, P., Gregory, J., Hegerl, G., Heimann, M., Hewitson, B., Hoskins, B., Joos, F., Jouzel, J., Kattsov, V., Lohmann, U., Manning, M., Matsuno, T., Molina, M., Nicholls, N., Overpeck, J., Qin, D., Raga, G., Ramaswamy, V., Ren, J., Rusticucci, M., Solomon, S., Somerville, R., Stocker, T. F., Stott, P., Stouffer, R. J., Whetton, P., Wood, R. A., and Wratt, D.: Climate change 2007: The physical science basis. Summary for policymakers, Intergovernmental Panel on Climate Change, Geneva, 2007.

Arrigo, K. R., Robinson, D. H., Worthen, D. L., Dunbar, R. B., DiTullio, G. R., VanWoert, M., and Lizotte, M. P.: Phytoplankton community structure and the drawdown of nutrients and $\mathrm{CO}_{2}$ in the Southern Ocean, Science, 283, 365-367, 1999.

Arrigo, K. R., Ditullio, G. R., Dunbar, R. B., Robinson, D. H., VanWoert, M., Worthen, D. L., and Lizotte, M. P.: Phytoplankton taxonomic variability in nutrient utilization and primary production in the Ross Sea, J. Geophys Res., 105, 8827-8846, 2000.

Bertrand, E. M., Saito, M. A., Rose, J. M., Riesselman, C. R., Lohan, M. C., Noble, A. E., Lee, P. A., and DiTullio, G. R.: Vitamin $\mathrm{B}_{12}$ and iron colimitation of phytoplankton growth in the Ross Sea, Limnol. Oceanogr., 52, 1079-1093, 2007.

Blank, G. S., Robinson, D. H., and Sullivan, C. W.: Diatom mineralization of silicic acid VIII. metabolic requirements and the timing of protein synthesis, J. Phycol., 22, 382-389, 1986.

Boyd, P. W., LaRoche, J., Gall, M., Frew, R. D., and McKay, R.: Role of iron, light and silicate in controlling algal biomass in subantarctic waters SE of New Zealand, J. Geophys Res., 104, 13391-13404, 1999.

Boyd, P. W., Watson, A. J., Law, C. S., Abraham, E. R., Trull, T., Murdoch, R., Bakker, D. C. E., Bowie, A. R., Buesseler, K. O., Chang, H., Charette, M., Croot, P., Downing, K., Frew, R., Gall, M., Hadfield, M., Hall, J., Harvey, M., Jameson, G., LaRoche, J., Liddicoat, M., Ling, R., Maldonado, M. T., McDay, R. M., Nodder, S., Pickmere, S., Pridmore, R., Rintoul, S., Safi, K., Sutton, P., Strzepek, R., Tanneberger, K., Turner, S., Waite, A., and Zeldis, J.: A mesoscale phytoplankton bloom in the polar Southern Ocean stimulated by iron fertilization, Nature, 407, 695-702, 2000.

Boyd, P. W., Crossley, C., DiTullio, G. R., Griffiths, F. B., Hutchins, D. A., Queguiner, B., Sedwick, P. N., and Trull, T. W.: Control of phytoplankton growth by iron supply and irradiance in the subantarctic Southern Ocean: experimental results from the SAZ project, J. Geophys Res., 106, 31573-31583, 2001.

Boyd, P. W. and Doney, S. C.: Modelling regional responses by marine pelagic ecosystems to global climate change, Geophys. Res. Lett., 29, 1806, doi:10.1029/2001GL014130, 2002.

Bruland, K. W., Rue, E. L., Smith, G. J., and DiTullio, G. R.: Iron, macronutrients and diatom blooms in the Peru upwelling regime: brown and blue waters of Peru, Mar. Chem., 93, 81-103, 2005.

Brzezinski, M. A. and Nelson, D. M.: The annual silica cycle in the Sargasso Sea near Bermuda, Deep-Sea Res. I, 42, 1215-1237, 1995.
Bucciarelli, E., Pondaven, P., and Sarthou, G.: Effects of an ironlight co-limitation on the elemental composition $(\mathrm{Si}, \mathrm{C}, \mathrm{N})$ of the marine diatoms Thalassiosira oceanica and Ditylum brightwellii, Biogeosciences Discuss., 6, 7175-7205, 2009,

http://www.biogeosciences-discuss.net/6/7175/2009/.

Buck, K. N., Lohan, M. C., Berger, C. J. M., and Bruland, K. W.: Dissolved iron speciation in two distinct river plumes and an estuary: Implications for riverine iron supply, Limnol. Oceanogr., 52, 843-855, 2007.

Campbell, L.: Flow cytometric analysis of autotrophic picoplankton, in: Methods in Microbiology, Academic Press, 317-341, 2001.

Caron, D. A., Dennett, M. R., Lonsdale, D. J., Moran, D. M., and Shalapyonok, L.: Microzooplankton herbivory in the Ross Sea, Antarctica, Deep-Sea Res. II, 47, 3249-3272, 2000.

Clarke, K. R. and Green, R. H.: Statistical design and analysis for a 'biological effects' study, Mar. Ecol-Prog. Ser., 46, 213-226, 1988.

Clarke, K. R.: Non-parametric multivariate analyses of changes in community structure, Aust. J. Ecol., 18, 117-143, 1993.

Clarke, K. R. and Warwick, R. M.: Change in marine communities: an approach to statistical analysis and interpretation, 2nd edition, Plymouth Marine Laboratory, Plymouth, UK, 2001.

Clarke, K. R. and Gorley, R. N.: Primer v6: user manual/tutorial, Primer-E Ltd, Plymouth, 190 pp., 2006.

Coale, K. H., Wang, X., Tanner, S. J., and Johnson, K. S.: Phytoplankton growth and biological response to iron and zinc addition in the Ross Sea and Antarctic Circumpolar Current along $170^{\circ} \mathrm{W}$, Deep-Sea Res. II, 50, 635-653, 2003.

Coale, K. H., Johnson, K. S., Chavez, F. P., Buesseler, K. O., Barber, R. T., Brzezinski, M. A., Cochlan, W. P., Millero, F. J., Falkowski, P. G., Bauer, J. E., Wanninkhof, R. H., Kudela, R. M., Altabet, M. A., Hales, B. E., Takahashi, T., Landry, M. R., Bidigare, R. R., Wang, X., Chase, Z., Strutton, P. G., Friederich, G. E., Gorbunov, M. Y., Lance, V. P., Hilting, A. K., Hiscock, M. R., Demarest, M., Hiscock, W. T., Sullivan, K. F., Tanner, S. J., Gordon, R. M., Hunter, C. N., Elrod, V. A., Fitzwater, S. E., Jones, J. L., Tozzi, S., Koblizek, M., Roberts, A. E., Herndon, J., Brewster, J., Ladizinsky, N., Smith, G., Cooper, D., Timothy, D., Brown, S. L., Selph, K. E., Sheridan, C. C., Twining, B. S., and Johnson, Z. I.: Southern Ocean iron enrichment experiment: carbon cycling in high- and low-Si waters, Science, 304, 408-414, 2004.

De Baar, H. J. W., Buma, A. G. J., Nolting, R. F., Cadee, G. C., Jacques, G., and Treguer, P. J.: On iron limitation of the Southern Ocean: experimental observations in the Weddell and Scotia Seas, Mar. Ecol-Prog. Ser., 65, 105-122, 1990.

del Valle, D. A., Kieber, D. J., Toole, D. A., Bisgrove, J., and Kiene, R. P.: Dissolved DMSO production via biological and photochemical oxidation of dissolved DMS in the Ross Sea, Antarctica, Deep-Sea Res. I, 56, 166-177, 2009.

Dennett, M. R., Mathot, S., Caron, D. A., Smith Jr., W. O., and Lonsdale, D. J.: Abundance and distribution of phototrophic and heterotrophic nano- and microplankton in the southern Ross Sea, Deep-Sea Res. II, 48, 4019-4037, 2001.

DiTullio, G. R. and Smith Jr., W. O.: Relationship between dimethylsulfide and phytoplankton pigment concentrations in the Ross Sea, Antarctica, Deep-Sea Res. I, 42, 873-892, 1995. 
DiTullio, G. R. and Smith Jr., W. O.: Spatial patterns in phytoplankton biomass and pigment distributions in the Ross Sea, J. Geophys. Res., 101, 18467-18478, 1996.

Donat, J. R. and Bruland, K. W.: Direct determination of dissolved cobalt and nickel in seawater by differential pulse cathodic stripping voltammetry preceded by adsorptive collection of cyclohexane-1, 2-dione dioxime complexes, Anal. Chem., 60, 240-244, 1988

Ellwood, M. and Van den Berg, C. M. G.: Zinc speciation in the Northeastern Atlantic Ocean, Mar. Chem., 68, 295-306, 2000.

Eppley, R. W.: Temperature and phytoplankton growth in the sea, Fish. Bull., 70, 1063-1085, 1972.

Feng, Y., Hare, C. E., Leblanc, K., DiTullio, G. R., Lee, P. A., Wilhelm, S. W., Sun, J., Rose, J. M., Nemcek, N., Benner, I., and Hutchins, D. A.: The effects of increased $\mathrm{pCO}_{2}$ and temperature on the North Atlantic Spring Bloom: I. The phytoplankton community and biogeochemical response, Mar. Ecol-Prog. Ser., 388, 13-25, 2009.

Firme, G. F., Rue, E. L., Weeks, D. A., Bruland, K. W., and Hutchins, D. A.: Spatial and temporal variability in phytoplankton iron limitation along the California coast and consequences for $\mathrm{Si}, \mathrm{N}$, and $\mathrm{C}$ biogeochemistry, Global Biogeochem. Cy., 17, 1016, doi:10.1029/2001GB001824, 2003.

Fitzwater, S. E., Johnson, K. S., Gordon, R. M., Coale, K. M., and Smith, W. O., Jr: Trace metal concentrations in the Ross Sea and their relationship with nutrients and phytoplankton growth, Deep-Sea Res. II, 47, 3159-3179, 2000.

Garrison, D. L.: An overview of the abundance and role of protozooplankton in Antarctic waters, J. Marine Syst., 2, 317-331, 1991.

Garrison, D. L. and Gowing, M. M.: Protozooplankton, in: Antarctic Microbiology, edited by: Friedmann, E. I., Wiley-Liss, New York, 123-166, 1993.

Garrison, D. L., Gibson, A., Kunze, H., Gowing, M. M., Vickers, C. L., Mathot, S., and Bayre, R. C.: The Ross Sea Polynya Project: diatom- and Phaeocystis-dominated phytoplankton assemblages in the Ross Sea, Antarctica, 1994 and 1995, in: Biogeochemistry of the Ross Sea, edited by: DiTullio, G. R. and Dunbar, R. B., American Geophysical Union, Washington, DC, 53-76, 2003.

Genty, B., Briantais, J. M., and Baker, N. R.: The relationship between the quantum yield of photosynthetic electron transport and quenching of chlorophyll fluorescence, Biochim. Biophys. Acta, 990, 87-92, 1989.

Gervais, F., Riebesell, U., and Gorbunov, M. Y.: Changes in primary productivity and chlorophyll $a$ in response to iron fertilization in the Southern Polar Frontal Zone, Limnol. Oceanogr., 47, 1324$1335,2002$.

Goldman, J. C. and Carpenter, E. J.: A kinetic approach to the effect of temperature on algal growth, Limnol. Oceanogr., 19, 756-766, 1974.

Goldman, J. C.: Temperature effects on steady-state growth, phosphorus uptake, and the chemical composition of a marine phytoplankter, Microb. Ecol., 5, 153-166, 1979.

Green, R. M., Kolber, Z. S., Swift, D. G., Tindale, N. W., and Falkowski, P. G.: Physiological limitation of phytoplankton photosynthesis in the Eastern Equatorial Pacific determined from variability in the quantum yield of fluorescence, Limnol. Oceanogr., 39, 1061-1074, 1994.

Haberman, K. L., Quetin, L. B., and Ross, R. M.: Diet of the
Antarctic krill (Euphausia superba, Dana): I. Comparisons of grazing on Phaeocystis antarctica (Karsten) and Thalassiosira antarctica (Comber), J. Exp. Mar. Biol. Ecol., 283, 79-95, 2003.

Haberman, K. L., Ross, R. M., and Quetin, L. B.: Diet of the Antarctic krill (Euphausia superba Dana): II. Selective grazing in mixed phytoplankton assemblages, J. Exp. Mar. Biol. Ecol., 283, 97-113, 2003.

Hare, C. E., DiTullio, G. R., Trick, C. G., Wilhelm, S. W., Bruland, K. W., Rue, E. L., and Hutchins, D. A.: Phytoplankton community structure changes following simulated upwelled iron inputs in the Peru upwelling region, Aquat. Microb. Ecol., 38, 269-282, 2005.

Hare, C. E., Leblanc, K., DiTullio, G. R., Kudela, R. M., Zhang, Y., Lee, P. A., Riseman, S. F., and Hutchins, D. A.: Consequences of increased temperature and $\mathrm{CO}_{2}$ for phytoplankton community structure in the Bering Sea, Mar. Ecol-Prog. Ser., 352, 9-16, doi:10.3354/meps07182, 2007.

Henjes, J., Assmy, P., Klaas, C., Verity, P. G., and Smetacek, V.: Response of microzooplankton (protists and small copepods) to an iron-induced phytoplankton bloom in the Southern Ocean (EisenEx), Deep-Sea Res. I, 54, 363-384, 2007.

Hutchins, D. A. and Bruland, K. W.: Iron-limited diatom growth and $\mathrm{Si}: \mathrm{N}$ uptake ratios in a coastal upwelling regime, Nature, 393, 561-564, 1998.

Hutchins, D. A., Campbell, B. J., Cottrell, M. T., Takeda, S., and Cary, S. C.: Response of marine bacterial community composition to iron additions in three iron-limited regimes, Limnol. Oceanogr., 46, 1535-1545, 2001.

Hutchins, D. A., Hare, C. E., Weaver, R. S., Zhang, Y., Firme, G. F., DiTullio, G. R., Alm, M. B., Riseman, S. F., Maucher, J. M., Geesey, M. E., Trick, C. G., Smith, G. J., Rue, E. L., Conn, J., and Bruland, K. W.: Phytoplankton iron limitation in the Humboldt Current and Peru Upwelling, Limnol. Oceanogr., 47, 997-1011, 2002.

Jacobs, S. S., Giulivi, C. F., and Mele, P. A.: Freshening of the Ross Sea during the late 20th century, Science, 297, 386-389, 2002.

Jacobson, D. M. and Anderson, D. M.: Thecate heterotrophic dinoflagellates: feeding behaviors and mechanisms, J. Phycol., 22, 249-258, 1986.

Kiene, R. P. and Slezak, D.: Low dissolved DMSP concentrations in seawater revealed by small-volume gravity filtration and dialysis sampling, Limnol. Oceanogr-Meth., 4, 80-95, 2006.

Kiene, R. P., Kieber, D. J., Slezak, D., Toole, D. A., del Valle, D. A., Bisgrove, J., Brinkley, J., and Rellinger, A.: Distribution of cycling of dimethylsulfide, dimethylsulfoniopropionate, and dimethylsulfoxide during spring and early summer in the Southern Ocean south of New Zealand, Aquat. Sci., 69, 305319, 2007.

Kolber, Z. S., Barber, R. T., Coale, K. H., Fitzwater, S. E., Greene, R. M., Johnson, K. S., Lindley, S., and Falkowski, G. P.: Iron limitation of the phytoplankton photosynthesis in the equatorial Pacific Ocean, Nature, 371, 145-149, 1994.

Leblanc, K., Hare, C. E., Boyd, P. W., Bruland, K. W., Sohst, B., Pickmere, S., Lohan, M. C., Buck, K., Ellwood, M., and Hutchins, D. A.: Fe and $\mathrm{Zn}$ effects on the Si cycle and diatom community structure in two contrasting high and low-silicate HNLC areas, Deep-Sea Res. I, 52, 1842-1864, 2005.

Leventer, A. R. and Dunbar, R. B.: Factors affecting the distribution of diatoms and other algae in the Ross Sea, J. Geophys. Res., 101, 
18489-18500, 1996.

Lomas, M. W. and Glibert, P. M.: Interactions between $\mathrm{NH}_{4}^{+}$and $\mathrm{NO}_{3}^{-}$uptake and assimilation: comparison of diatoms and dinoflagellates at several growth temperatures, Mar. Biol., 133, 541-551, 1999.

Martin-Jezequel, V., Hildebrand, M., and Brzezinski, M. A.: Silicon metabolism in diatoms: implications for growth, J. Phycol., 36, 821-840, 2000.

Martin, J. H., Gordon, R. M., and Fitzwater, S. E.: Iron in Antarctic waters, Nature, 345, 156-158, 1990.

Maucher, J. M. and DiTullio, G. R.: Chronic iron limitation in the Ross Sea: Flavodoxin:Ferredoxin ratios in the Ross Sea, in: Biogeochemistry of the Ross Sea, edited by: DiTullio, G. R., and Dunbar, R. B., Antarctic Research Series, AGU Antarctic Research Series, Washington DC, 209-220, 2003.

Montes-Hugo, M. A., Doney, S. C., Ducklow, H. W., Fraser, W., Martinson, D., Stammerjohn, S. E., and Schofiield, O.: Recent changes in phytoplankton communities associated with rapid regional climate change along the Western Antarctic Peninsula, Science, 323, 1470-1473, 2009.

Noiri, Y., Kudo, I., Kiyosawa, H., Nishioka, J., and Tsuda, A.: Influence of iron and temperature on growth, nutrient utilization ratios and phytoplankton species composition in the western subarctic Pacific Ocean during the SEEDS experiment, Prog. Oceanogr., 64, 149-166, 2005.

Olson, R. J., Sosik, H. M., Chekalyuk, A. M., and Shalapyonok, A.: Effects of iron enrichment on phytoplankon in the Southern Ocean during late summer: active fluorescence and flow cytometric analyses, Deep-Sea Res. II, 47, 3181-3200, 2000.

Overpeck, J. T., Otto-Bliesner, B. L., and Miller, G. H.: Paleoclimatic evidence for future ice-sheet instability and rapid sea-level rise, Science, 311, 1747-1750, 2006.

Paasche, E.: Silicon, in: The physiological ecology of phytoplankton, edited by: Morris, I., Studies in Ecology, University of California Press, Berkeley, CA, 259-284, 1980.

Pondaven, P., Gallinari, M., Chollet, S., Bucciarelli, E., Sarthou, G., Schultes, S., and Jean, F.: Grazing-induced changes in cell wall silicification in a marine diatom, Protist, 158, 21-28, 2007.

Raiswell, R., Tranter, M., Benning, L. G., Siegert, M., De'ath, R., Huybrechts, P., and Payne, T.: Contributions from glacially derived sediment to the global iron (oxyhydr)oxide cycle: implications for iron delivery to the oceans, Geochim. Cosmochim. Ac., 70, 2765-2780, 2006.

Raiswell, R., Benning, L., Tranter, M., and Tulaczyk, S.: Bioavailable iron in the Southern Ocean: the significance of the iceberg conveyor belt, Geochem. T., 9, 7, doi:10.1186/1467-4866-9-7, 2008.

Raven, J. A. and Geider, R. J.: Temperature and algal growth, New Phytol., 110, 441-461, 1988.

Rellinger, A. N., Kiene, R. P., del Valle, D. A., Kieber, D. J., Slezak, D., Harada, H., Bisgrove, J., and Brinkley, J.: Occurrence and turnover of DMSP and DMS in deep waters of the Ross Sea, Antarctica, Deep-Sea Res. I, 56, 686-702, 2009.

Revel-Rolland, M., De Deckker, P., Delmonte, B., Hesse, P. P., Magee, J. W., Basile-Doelsch, I., Grousset, F., and Bosch, D.: Eastern Australia: a possible source of dust in East Antarctica interglacial ice, Earth Planet. Sc. Lett., 249, 1-13, 2006.
Rose, J. M. and Caron, D. A.: Does low temperature constrain the growth rates of heterotrophic protists? Evidence and implications for algal blooms in cold waters, Limnol. Oceanogr., 52, 886-895, 2007.

Rose, J. M., Feng, Y., Gobler, C. J., Gutierrez, R., Hare, C. E., Leblanc, K., and Hutchins, D. A.: The effects of increased $\mathrm{pCO}_{2}$ and temperature on the North Atlantic Spring Bloom. II. Microzooplankton abundance and grazing, Mar. Ecol-Prog. Ser., 388, 27-40, 2009.

Sarmiento, J. L., Hughes, T. M. C., Stouffer, R. J., and Manabe, S.: Simulated response of the ocean carbon cycle to anthropogenic climate warming, Nature, 393, 245-249, 1998.

Scharek, R., van Leeuwe, M. A., and de Baar, H. J. W.: Responses of Southern Ocean phytoplankton to the addition of trace metals, Deep-Sea Res. II, 44, 209-227, 1997.

Sedwick, P. N. and DiTullio, G. R.: Regulation of algal blooms in Antarctic shelf waters by the release of iron from melting sea ice, Geophys. Res. Lett., 24, 2515-2518, 1997.

Sedwick, P. N., DiTullio, G. R., and Mackey, D. J.: Iron and manganese in the Ross Sea, Antarctica: seasonal iron limitation in Antarctic shelf waters, J. Geophys. Res., 105, 11321-11332, 2000.

Smith Jr., W. O., Marra, J., Hiscock, M. R., and Barber, R. T.: The seasonal cycle of phytoplankton biomass and primary productivity in the Ross Sea, Antarctica, Deep-Sea Res. II, 47, 3119-3140, 2000.

Smith Jr., W. O., Dennett, M. R., Mathot, S., and Caron, D. A.: The temporal dynamics of the flagellated and colonial stages of Phaeocystis antarctica in the Ross Sea, Deep-Sea Res. II, 50, 605-617, 2003.

Solorzano, L. and Sharp, J. H.: Determination of total dissolved phosphorus and particulate phosphorus in natural waters, Limnol. Oceanogr., 25, 756-760, 1980.

Strom, S., Wolfe, G., Holmes, J., Stecher, H., Shimeneck, C., Lambert, S., and Moreno, E.: Chemical defense in the microplankton I. Feeding and growth rates of heterotrophic protists on the DMSproducing phytoplankter Emiliana huxleyi, Limnol. Oceanogr., 48, 217-229, 2003.

Sunda, W. G. and Huntsman, S. A.: Interrelated influence of iron, light, and cell size on growth of marine phytoplankton, Nature, 390, 389-392, 1997.

Sunda, W. G., Kieber, D. J., Kiene, R. P., and Huntsman, S. A.: An antioxidant function for DMSP and DMS in marine algae, Nature, 418, 317-320, 2002.

Takeda, S.: Influence of iron availability on nutrient consumption ratio of diatoms in oceanic waters, Nature, 393, 774-777, 1998.

Thamatrakoln, K. and Hildebrand, M.: Silicon uptake in diatoms revisited: a model for saturable and nonsaturable uptake kinetics and the role of silicon transporters, Plant Physiol., 146, 13971407, 2008.

Throndsen, J.: Preservation and storage, in: Phytoplankton manual, edited by: Sournia, A., UNESCO, Paris, 69-74, 1978.

Twining, B. S., Baines, S. B., Fisher, N. S., and Landry, M. R.: Cellular iron contents of plankton during the Southern Ocean Iron Experiment (SOFeX), Deep-Sea Res. I, 51, 1827-1850, 2004.

Twining, B. S., Baines, S. B., Vogt, S., and De Jonge, M.: Exploring ocean biogeochemistry by single-cell microprobe analysis of protist elemental composition, J. Eukaryot. Microbiol., 55, 151$162,2008$. 
Utermöhl, H.: Zur Vervollkommung der quantitativen phytoplankton-methodik, Mitt. Int. Ver. Limnol., 9, 1-38, 1958.

Vaughan, D. G., Marshall, G. J., Connolley, W. M., Parkinson, C., Mulvaney, R., Hodgson, D. A., King, J. C., Pudsey, C. J., and Turner, J.: Recent rapid regional climate warming on the Antarctic Peninsula, Clim. Change, 60, 243-274, 2003.

Vogt, M., Steinke, M., Turner, S., Paulino, A., Meyerhöfer, M., Riebesell, U., LeQuéré, C., and Liss, P.: Dynamics of dimethylsulphoniopropionate and dimethylsulphide under different $\mathrm{CO}_{2}$ concentrations during a mesocosm experiment, Biogeosciences, 5, 407-419, 2008, http://www.biogeosciences.net/5/407/2008/.

Welschmeyer, N. A.: Fluorometric analysis of chlorophyll a in the presence of chlorophyll $\mathrm{b}$ and phaeopigments, Limnol. Oceanogr., 39, 1985-1992, 1994.
Wilcox, R. R.: Applying contemporary statistical techniques, Academic Press, New York, 608 pp., 2003.

Wingenter, O. W., Haase, K. B., Zeigler, M., Blake, D. R., Rowland, F. S., Sive, B. C., Paulino, A., Thyrhaug, R., Larsen, A., Schulz, K., Meyerhofer, M., and Riebesell, U.: Unexpected consequences of increasing $\mathrm{CO}_{2}$ and ocean acidity on marine production of DMS and $\mathrm{CH}_{2} \mathrm{Cl}$ 1. Potential climate impacts, Geophys. Res. Lett., 34, L05710, doi:10.1029/2006GL028139, 2007.

Wolfe, G. V. and Steinke, M.: Grazing-activated production of dimethylsulfide (DMS) by two clones of Emiliania huxleyi, Limnol. Oceanogr., 41, 1151-1160, 1996.

Wolfe, G. V., Steinke, M., and Kirst, G. O.: Grazing-activated chemical defence in a unicellular marine alga, Nature, 387, 894897, 1997. 